\title{
SKIRTINGOSE APLINKOSE ATLIKTO VIENKARTINIO AEROBINIO KRŪVIO POVEIKIS VYRŲ KOGNITYVINĖMS FUNKCIJOMS
}

\author{
Gerda Gudliauskaité ${ }^{1}$, Ligita Šiliné $\dot{e}^{1,2}$ \\ Kauno kolegijal \\ Lietuvos sporto universitetas ${ }^{2}$
}

\section{SANTRAUKA}

Tyrimo pagrindimas. Mokslininkai aptinka vis daugiau sąsajų tarp kognityvinių funkcijų ir fizinio aktyvumo. Visgi dauguma tyrimų, nagrinėjančių vienkartinio aerobinio krūvio poveikị kognityvinèms funkcijoms, yra atliekami laboratorinèmis sąlygomis, todėl trūksta informacijos apie skirtingose aplinkose atliekamo vienkartinio aerobinio krūvio poveikị kognityvinėms funkcijoms.

Tikslas - nustatyti skirtingose aplinkose atlikto vienkartinio aerobinio krūvio poveiki vyrų kognityvinèms funkcijoms.

Metodai. Buvo tiriama 10 fiziškai aktyvių sveikų 23,2 $\pm 2,2$ metų amžiaus vyrų. Buvo taikomas 20 minučių vienkartinis aerobinis krūvis miško, miesto ir uždaroje (salès) aplinkose. Prieš krūvị ir po jo kiekvienoje aplinkoje vertintos kognityvinès funkcijos „Stroop“ bei „Kelio paieškos“ testais.

Rezultatai. Protinis lankstumas ( $<<0,05 ; \mathrm{p}=0,01)$ reikšmingai pagerejo miško aplinkoje, lyginant su miesto aplinka. Taip pat pastebèta, kad demesys $(\mathrm{p}<0,05 ; \mathrm{p}=0,01)$, reakcijos greitis $(\mathrm{p}<$ $0,05 ; \mathrm{p}=0,02)$ ir protinis lankstumas $(\mathrm{p}<0,05 ; \mathrm{p}=0,01)$ reikšmingai pagerèjo krūvị atliekant miško aplinkoje, lyginant su salès aplinka.

Išvados. Vienkartinis aerobinis krūvis, atliktas tiek ramioje miško, tiek miesto, tiek uždaroje (salès) aplinkose, reikšmingai pagerino kognityvines funkcijas. Nustatyta, kad protinis lankstumas reikšmingai pagerejo miško aplinkoje, lyginant su miesto ar uždara aplinka, o dėmesys ir reakcijos greitis statistiškai reikšmingai pagerėjo atliekant krūvị miško aplinkoje, lyginant su salès aplinka.

Raktažodžiai: vienkartinis aerobinis krūvis, vyrai, kognityvinès funkcijos, aplinka.

\section{IVADAS}

Mokslininkai teigia, kad natūrali aplinka teigiamai veikia žmogaus sveikatą: mažina stresą, gerina nuotaiką, stimuliuoja galvos smegenų veiklą (Gidlow et al., 2015; Zijlema et al., 2017). Anot A. Skurvydo (2016), norint teigiamai stimuliuoti kognityvini intelektą, emocijas ir nuotaiką, pravartu taikyti aerobinius pratimus įdomioje aplinkoje, gamtoje. Dauguma tyrimų teigia, kad po pasivaikščiojimo natūralioje aplinkoje dèmesio ir atminties funkcijų pažanga didesnè, nei po pasivaikščiojimo mieste (Gidlow et al., 2015; Zijlema et al., 2017).

Yra dvi teorijos, aiškinačios teigiamą natūralios aplinkos poveiki kognityvinèms funkcijoms: dèmesio koncentracijos teorija ir streso mažinimo teorija (Zijle-

Copyright (C) 2020 Gerda Gudliauskaitė, Ligita Šilinè. Published by Lithuanian Sports University.

This is an Open Access article distributed under the terms of the Creative Commons Attribution 4.0 International License, which permits unrestricted use, distribution, and reproduction in any medium, provided the original author and source are credited. 
Skirtingose aplinkose atlikto vienkartinio aerobinio krūvio poveikis vyrų kognityvinèms funkcijoms

ma et al., 2017). Démesio koncentracijos teorija paremta tuo, kad natūralioje aplinkoje lengviau sutelkti dèmesį, nèra daug dirgiklių, kurie galètų ji nukreipti. Tai gerina dèmesio sutelkimo funkciją ir jos atsinaujinimą (Ohly et al., 2016). Kita streso mažinimo teorija remiasi tuo, kad natūrali aplinka mažina streso hormono kortizolio kiekị žmogaus organizme, padeda sumažinti susijaudinimą ir negatyvias mintis (Zijlema et al., 2017).

Manoma, kad natūralioje aplinkoje mažesnis oro užterštumas ir triukšmingumas (Gidlow et al., 2015). Miesto aplinkoje yra daug stimulų, tokių kaip eismas, žmonių minios, ir tai reikalauja sutelkti dèmesį, vengti blaškymo. Dèl to pasireiškia kognityvinis nuovargis, lètai ir sudètingai atsigauna psichika (Zijlema et al., 2017).

Nustatyta, kad vienkartinis vidutinio intensyvumo aerobinis krūvis tegiamai veikia kognityvines funkcijas (Chang et al., 2015, 2017; Bae, Masaki, 2019), bet tyrimai atlikti laboratorinėmis sąlygomis ir neịvertintas aplinkos poveikis. Vis dar trūksta duomenų, kaip vienkartinis aerobinis krūvis veikia kognityvines funkcijas ir kaip jos priklauso nuo aplinkos.

Tyrimo tikslas - nustatyti skirtingose aplinkose atlikto vienkartinio aerobinio krūvio poveikị vyrų kognityvinėms funkcijoms.

\section{METODAI}

Tiriamieji. Buvo tiriama 10 savanoriškai sutikusių dalyvauti jaunų vyrų. Tik vyriškoji lytis buvo pasirinkta todèl, kad būtų išlaikomas kuo didesnis tiriamujų homogeniškumas. Tirti 23,2 \pm 2,2 metu amžiaus asmenys, neturintys sveikatos problemų ir profesionaliai nesportuojantys.

Tyrimo organizavimas. Prieš atliekant tyrimą buvo gautas Kauno kolegijos Bioetikos komisijos leidimas. Kiekvienas tiriamasis užpildẻ asmens informavimo formą. Visi tyrimo asmenys tyrime dalyvavo savo noru. Prieš tyrimą tiriamieji buvo išmokyti kognityvinių funkcijų testų. Visus kognityvinius testus jie atliko po du kartus. Tada nustatytas maksimalusis širdies susitraukimų dažnis ir apskaičiuotos intensyvumo ribos. Tiriamieji buvo supažindinti su fiziniu krūviu ir paaiškinta, kad tyrimo metu reikès palaikyti atitinkamą širdies susitraukimų dažni (jei dažnis per žemas - didinti bėgimo tempą, jei per didelis - mažinti). Tyrimas buvo atliekamas miško, miesto bei uždaroje (salès) aplinkose. Miško ir salès aplinkos buvo ramios, netriukšmingos, o miesto aplinka - triukšminga. Tyrimą sudare trys etapai. Kiekvienas tiriamasis buvo tiriamas tris dienas. Kiekvieno etapo metu tiriamieji atliko tą patị vienkartinị aerobinị krūvị ir sprendè tuos pačius kognityvinius testus, bet skirtingoje aplinkoje. Pirmą dieną vienkartinis aerobinis krūvis buvo atliktas ramioje miško aplinkoje, antrą - triukšmingoje miesto aplinkoje, trečią - uždaroje aplinkoje (salëje). Prieš pat vienkartinị aerobinị krūvị tiriamieji atliko „Stroop“ 
ir „Kelio paieškos“ kognityvinių funkcijų testus. Vienkartinis aeorobinis krūvis truko 20 minučių. Tiriamieji krūvio metu savo širdies susitraukimų dažnį stebejjo išmaniaisiais „Polar A300“ laikrodžiais. Tik baigus aerobinį krūvị, tiriamieji dar kartą atliko „Stroop“ ir „Kelio paieškos“ kognityvinių funkcijų testus. Tarp tyrimo etapų išlaikytas 24 valandų laiko tarpas. Visi testavimai buvo atliekami tuo pačiu paros metu.

\section{Tyrimo metodai}

Aerobinis krūvis. Tyrimo metu buvo taikomas aerobinis krūvis (bėgimas), kurio intensyvumas - 60-70\% nuo maksimaliojo širdies susitraukimų dažnio (ŠSD). Maksimalusis ŠSD buvo apskaičiuojamas pagal formulę: 208 - 0,7 x amžius (Tanaka et al., 2001).

„Stroop“ testas (Stroop, 1935) plačiai naudojamas vertinant reakcijos greiti ir vykdančiąsias funkcijas. Atliekant testą kompiuterio ekrane matomi žodžiai: raudona, žalia, mèlyna ir geltona, kurie parašyti raudona, žalia, mèlyna arba geltona spalvomis. Tiriamieji yra instruktuojami kuo greičiau ir kuo tiksliau reaguoti ne ị žodžio reikšmę, bet ị spalvą, kuria parašytas žodis. Tiriamasis, ekrane išvydęs žodị, yra prašomas kompiuterio klaviatūroje pasirinkti reikiamą spalvą. Vertinamas tiriamujų reakcijos greitis, reakcijos greitis, kai stimulo reikšmė ir spalva sutampa, reakcijos greitis, kai stimulo spalva ir reikšmė nesutampa, klaidų skaičius, interferencija. Interferencija apskaičiuojama iš vidutinio reakcijos greičio, kai stimulo reikšmè ir spalva nesutampa, atėmus vidutini reakcijos greitị, kai stimulo spalva ir reikšmè sutampa, gautą skaičių padalijus iš vidutinio reakcijos greičio, kai stimulo reikšmė ir spalva sutampa ir galiausiai gautą skaičių padauginus iš 100 procentų. Interferencijos rodikliu vertinamas atsako slopinimas - vykdančiosios funkcijos dalis. Kuo didesnis interferencijos procentas, tuo atsako slopinimo funkcija prastesnè (Weinstein et al., 2011).

„Kelio paieškos “ testu vertinamas dèmesys, vizualieji gebejjimai ir protinis lankstumas. Šị testą 1992 sukūrẻ R. Reitan'as ir D. Wolfston'as. Testas sudarytas iš dviejų dalių (A ir B). A dalyje lape atsitiktine tvarką yra išdèstyta 15 apskritimų, kiekviename apskritime yra po vieną skaičių nuo 1 iki 15. Šioje dalyje tiriamasis yra prašomas sujungti visus apskritimus didèjančia tvarka nuo 1 iki 15 . B dalis sudètingesnè. Apskritimuose išdèstyti skaičiai (1-13) ir raidès (A-L). Tiriamasis pradeda nuo pirmo skaičiaus, tada nuo pirmo skaičiaus brěžia kelią iki pirmos abėcèlès raidès, paskui brèžia kelią iki antro skaičiaus ir taip toliau (1-A, 2-B, 3-C). Vertinimo rodiklis - laikas, per kurị tiriamasis nupiešia visą „kelią“. Jei tiriamasis padaro klaidą, ši yra iškart parodoma tiriamajam ir taisoma. Darant klaidas ilgeja užduoties atlikimo laikas. Labai svarbu atsižvelgti ị tai, kad A dalies testas būtų atliekamas pirmiau nei B. A dalis vertina vizualiuosius gebejjimus, B dalis - protinị lankstumą. Taip pat išanalizuojamas rodiklis, gaunamas B dalies rodiklị padalijus 
Skirtingose aplinkose atlikto vienkartinio aerobinio krūvio poveikis vyrų kognityvinèms funkcijoms

iš A dalies rodiklio. Gautas rezultatas vertinamas taip: jei rodiklis mažesnis nei 2 - dèmesys yra geras, jei didesnis nei 2 - galimos dèmesio problemos (Reitan, Wolfston, 2013).

Matematinė statistika. Tyrimo duomenų statistinei analizei atlikti buvo naudojama SPSS (angl. Statistical Package for Social Science) programos 22.0 versija. Diagramoms pavaizduoti naudota MS Excel 2010 programa. Taikyti ir aprašomosios statistikos skaičiavimai (aritmetinis vidurkis ir standartinis nuokrypis). Taip pat naudotas Kalmogorovo-Smirnovo testas norint patikrinti, ar gauti duomenys yra pasiskirstę pagal normalujj skirstinį. Duomenų pokyčio reikšmingumas buvo vertinamas naudojant parametrinị priklausomų imčių $t$ testą. Rodikliams tarp aplinkų palyginti buvo apskaičiuotas skirtumas iš aritmetinio vidurkio po intervencijos atėmus aritmetinị vidurkị prieš intervenciją. Tarp miško ir miesto, tarp miesto ir salès, tarp miško ir salès aplinkų rodiklių skirtumų reikšmingumas nustatytas naudojant parametrinį nepriklausomų imčių $t$ testą.

\section{TYRIMO REZULTATAI}

İvertinus tiriamujų „Kelio paieškos“ A dalies testo rodiklius, kuriais vertinami vizualieji gebejjimai, nustatyta, kad po vienkartinio aerobinio krūvio miško ir salès

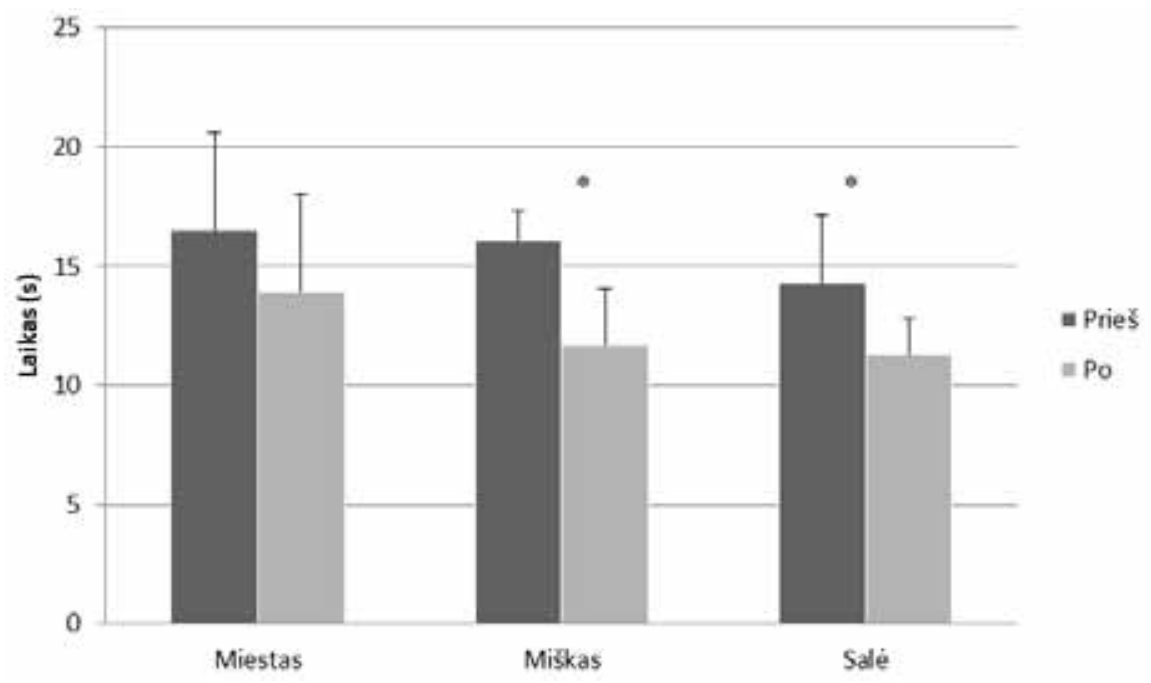

Pastaba. Pateikiant rodiklius nurodytas vidurkis \pm standartinis nuokrypis.

* $-\mathrm{p}<0,05$ - reikšmingas skirtumas prieš intervenciją ir po jos toje pačioje aplinkoje.

1 pav. Vizualieji gebèjimai prieš vienkartinị aerobinị krūvị skirtingose aplinkose ir po jo 


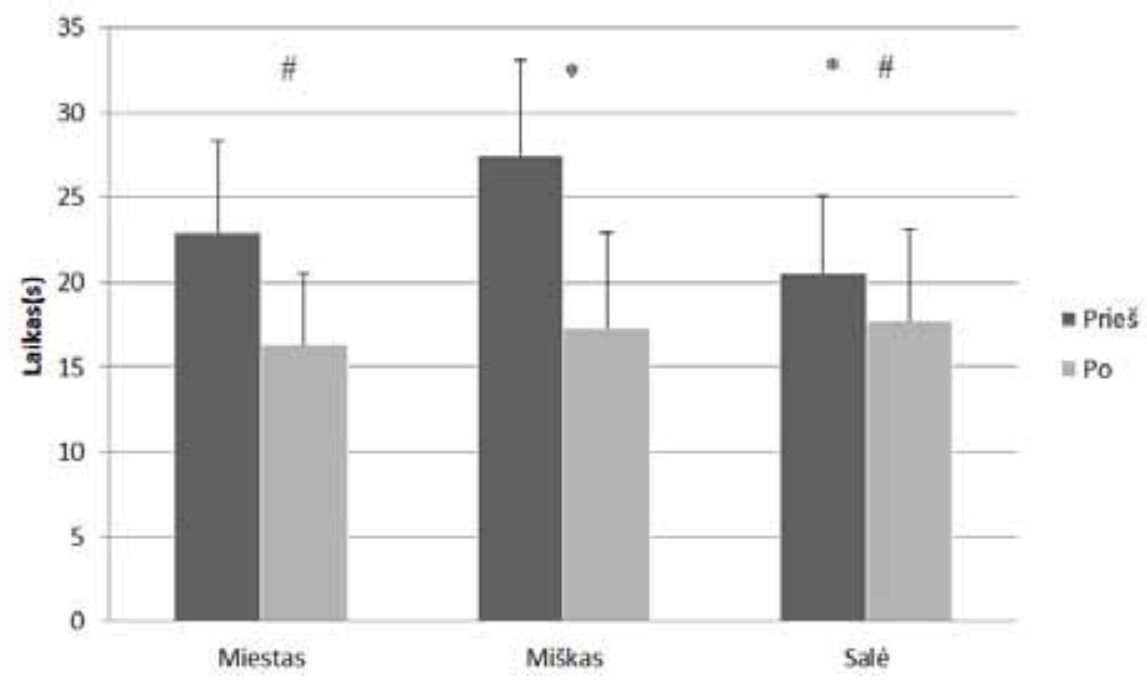

Pastaba. Pateikiant rodiklius nurodytas vidurkis \pm standartinis nuokrypis.

* $-\mathrm{p}<0,05$ - reikšmingas skirtumas prieš intervenciją ir po jos toje pačioje aplinkoje;

$\#-\mathrm{p}<0,05$ - reikšmingas skirtumas, lyginant rodiklius su miško aplinkos rodikliais.

\section{2 pav. Protinis lankstumas prieš vienkartinị aerobinị}

krūvị skirtingose aplinkose ir po jo

aplinkose pagerejo vizualiosios funkcijos $(\mathrm{p}<0,05)$, o miesto aplinkoje nepakito $(p>0,05)$. Lyginant rodiklius tarp aplinkų, reikšmingų skirtumų nenustatyta $(\mathrm{p}>0,05)(1$ pav.).

İvertinus tiriamujų „Kelio paieškos“ testo B dalies rodiklius, kuriais vertinama vykdančiosios funkcijos sudedamoji dalis - protinis lankstumas, nustatytas reikšmingas pagerẻjimas po aerobinio krūvio miško $(\mathrm{p}<0,05)$ bei salès $(\mathrm{p}<0,05)$ aplinkose. Po atlikto krūvio miesto aplinkoje reikšmingų skirtumų nenustatyta $(\mathrm{p}>0,05)$. Lyginant rodiklius tarp aplinkų, reikšmingas protinio lankstumo pagerejjimas nustatytas miško aplinkoje, lyginant rodiklius su miesto ir salès aplinkomis $(\mathrm{p}<0,05)(2$ pav. $)$.

Ivertinus tiriamųjų dėmesị, reikšmingas skirtumas nustatytas miško aplinkoje, lyginant rodiklius prieš intervenciją ir po jos $(\mathrm{p}<0,05)$. Atliktas krūvis miesto ir salès aplinkoje reikšmingo poveikio dèmesiui neturejo $(p>0,05)$. Lyginant rodiklius tarp aplinkų nustatyta, kad po aerobinio krūvio miško aplinkoje dèmesys reikšmingai pagėrèjo, lyginant su salès aplinkos rodikliais $(\mathrm{p}<0,05)(3$ pav. $)$.

İvertinus vidutinị reakcijos greitị „Stroop“ testu prieš vienkartinį aerobinị krūvị ir po jo, nustatytas reikšmingas skirtumas miško ir miesto aplinkose $(\mathrm{p}<0,05)$. Po 
Skirtingose aplinkose atlikto vienkartinio aerobinio krūvio poveikis vyrų kognityvinèms funkcijoms

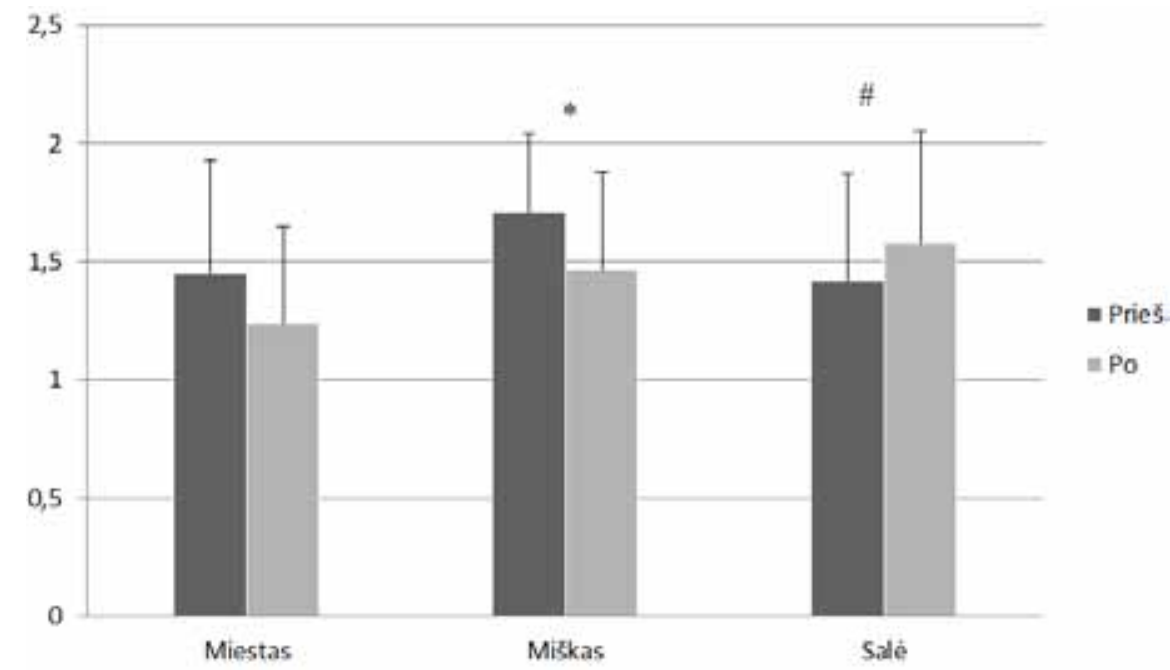

Pastaba. Pateikiant rodiklius nurodytas vidurkis \pm standartinis nuokrypis.

* $-\mathrm{p}<0,05$ - reikšmingas skirtumas prieš intervenciją ir po jos toje pačioje aplinkoje; $\#-\mathrm{p}<0,05-$ reikšmingas skirtumas, lyginant rodiklius su miško aplinkos rodikliais.

3 pav. Dẻmesys prieš vienkartinị aerobinị krūvị skirtingose aplinkose ir po jo

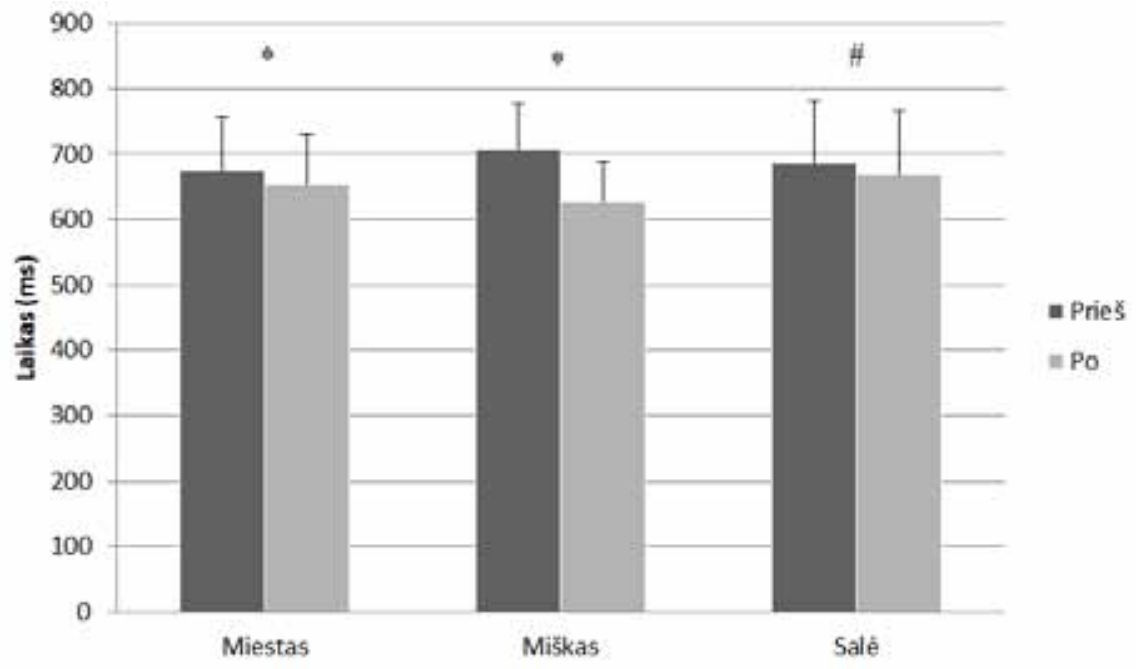

Pastaba. Pateikiant rodiklius nurodytas vidurkis \pm standartinis nuokrypis.

* $-\mathrm{p}<0,05$ - reikšmingas skirtumas prieš intervenciją ir po jos toje pačioje aplinkoje; $\#-\mathrm{p}<0,05-$ reikšmingas skirtumas, lyginant rodiklius su miško aplinkos rodikliais.

4 pav. Reakcijos greitis prieš vienkartinị aerobinị krūvị skirtingose aplinkose ir po jo 


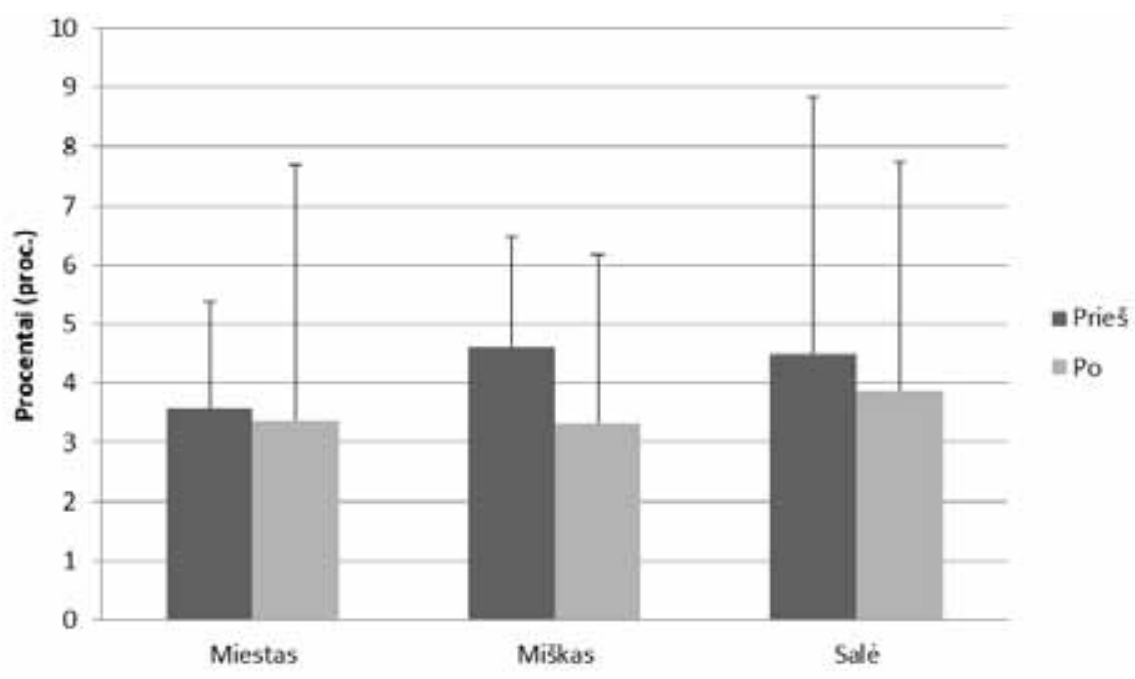

Pastaba. Pateikiant rodiklius nurodytas vidurkis \pm standartinis nuokrypis.

5 pav. Interferencija prieš vienkartinị aerobinị krūvị skirtingose aplinkose ir po jo

atlikto krūvio salëje reikšmingų pokyčių nepastebèta $(\mathrm{p}>0,05)$. Lyginant rodiklius tarp aplinkų nustatyta, kad miško aplinkoje reakcijos greitis reikšmingai pagerejo, lyginant su salès aplinka $(\mathrm{p}<0,05)(4$ pav. $)$.

İvertinus tiriamujjų interfecijos rodiklius prieš krūvị ir po jo, reikšmingų skirtumų nenustatyta $(\mathrm{p}>0,05)(5 \mathrm{pav}$.$) .$

\section{REZULTATŲ APTARIMAS}

Tyrimo tikslas buvo nustatyti skirtingoje aplinkoje atlikto vienkartinio aerobinio krūvio poveikị vyrų kognityvinėms funkcijoms. Y. K. Chang'o su bendraautoriais (2017) tyrimai parode, kad aerobiniai vidutinio intensyvumo pratimai teigiamai veikia kognityvines funkcijas, todèl ir šiame tyrime buvo taikytas vidutinio intensyvumo aerobinis krūvis. Taip pat nustatyta, kad efektyviausiai kognityvines funkcijas veikianti vienkartinio aerobinio krūvio trukmė yra 20 minučių (Chang et al., 2015; Wang et al., 2019).

Iš mūsų tyrimo matyti, kad vienkartinis aerobinis krūvis, atliktas miško aplinkoje, statistiškai reikšmingai pagerino tokias kognityvines funkcijas kaip vizualieji gebejjimai, protinis lankstumas, dėmesys ir reakcijos greitis. W. S. Shin'as su bendraautoriais (2011) atliko tyrimą, kurio metu buvo naudotas „Kelio paieškos“ tes- 
Skirtingose aplinkose atlikto vienkartinio aerobinio krūvio poveikis vyrų kognityvinèms funkcijoms

tas norint ịvertinti tiriamųjų protinị lankstumą ir demesị. Jo metu nustatyta, kad 50 minučių pasivaikščiojimas miško aplinkoje įveikiant 4,5 kilometrų nuotolị reikšmingai pagerino tiriamuju protini lankstumą ir dèmesio funkcijas.

Iš mūsų tyrimo duomenų matyti, kad vidutinis reakcijos laikas reikšmingai pagerèjo po vienkartinio aerobinio krūvio, atlikto miesto aplinkoje. Tuo tarpu M. Crous-Bou su bendraautoriais (2020) atliko tyrimą, kuriuo vertino ne krūvio, atlikto miesto aplinkoje, poveikị kognityvinèms funkcijos, bet pačios miesto aplinkos poveikį pažintinėms funkcijoms. Mokslininkai nenustatė reikšmingų sąsajų tarp vykdančiujų funkcijų ir miesto aplinkos. Remiantis mūsų ir M. Crous-Bou su bendraautorias (2020) tyrimo rezultatais, galima daryti prielaidą, kad miesto aplinka neblogina vykdančiụjų funkcijų, tačiau norint jas pagerinti naudinga atlikti vidutinio intensyvumo 20 minučių aerobinị krūvị.

Be to, vienkartinis aerobinis krūvis, atliktas uždaroje aplinkoje (salèje), pagerino tokias kognityvines funkcijas kaip vizualieji gebejjimai ir protinis lankstumas, tačiau panašių tyrimų, nagrinèjančių uždaros aplinkos poveikị smegenų veiklai ne laboratorinèmis sąlygomis, nepavyko rasti.

Taip pat nustatème, kad protinis lankstumas pagerejo po atlikto krūvio miško aplinkoje, lyginant su miesto ar uždara aplinka. Pastebejjome, kad dèmesys reikšmingai pagerejjo miško aplinkoje, lyginant su salès aplinka. Panašius duomenis rodo H. Ohly su bendraautoriais (2016) atlikta metaanalizè, kuria nustatytas reikšmingas poveikis dèmesio sukaupimui natūralioje aplinkoje, lyginant su nenatūralia aplinka. Mokslininkai ṣ̨̌ rezultatą aiškina remdamiesi Kaplanų dèmesio atkūrimo teorija (angl. Attention Restoration). Ši teorija teigia, kad buvimas žaliosiose erdvèse (gamtoje) ypač teigiamai veikia smegenų veiklą. Rami gamtos aplinka neblaško dèmesio ir padeda atkurti išeikvotas kognityvines jègas. Taip pat nereikètų pamiršti, kad ne tik aplinka, bet ir vienkartinis aerobinis krūvis lemia dèmesio funkcijos pagerejimą (Ohly et al., 2016).

Mokslininkai teigia, kad po vienkartinio fizinio krūvio (20 minučiu vidutiniu intensyvumu) vykdančiųų funkcijų testo metu smegenyse padidejja P3 amplitudè ir sutrumpejja P3 latentinis periodas (Hillman et al., 2003). Panašius neuronų aktyvacijos rodiklius, susijusius su fiziniu krūviu, patvirtina ir vèlesni tyrimai (Hillman et al., 2012; Drollette et al., 2014; Chang et al., 2017). Šie P3 pokyčiai rodo, kad po vienkartinio fizinio krūvio pagereja informacijos apdorojimo greitis, o po vidutinio intensyvumo aerobinio krūvio padidèja ir BDNF koncentracija (Goekint et al., 2008; Calvert et al., 2014). Be to, kognityvinių funkcijų pagerẻjimas gali būti susijęs ir su smegenų kraujotakos padidejjimu fizinio krūvio metu. Smegenyse pagerejja kraujotaka, daugiau patenka deguonies, kuris greičiau suvartojamas (Secher et al., 2008; Mozolic et al., 2010). Mūsų tyrimo duomenimis, po vienkartinio aerobinio 
krūvio gerejja kognityvinès funkcijos, o atlikus tyrimą atitinkamoje aplinkoje galima stipriau paveikti ir kognityvines funkcijas.

\section{IŠVADOS}

Vienkartinis aerobinis krūvis, atliktas tiek ramioje miško, tiek miesto, tiek uždaroje (salès) aplinkose, reikšmingai pagerino kognityvines funkcijas. Nustatėme, kad protinis lankstumas reikšmingai pagerejjo miško aplinkoje, lyginant su miesto ar uždara aplinka, o dėmesys reikšmingai pagerèjo miško aplinkoje, lyginant su salès aplinka.

Finansavimas: nèra

Interesų atskleidimas: nėra.

\section{LITERATŪRA}

Bae, S., Masaki, H. (2019). Effects of acute aerobic exercise on cognitive flexibility required during taskswitching paradigm. Frontiers in Human Neuroscience, 13, 260.

Calvert, H., Hwang, J., Kim, K. et al. (2014). The Impact of acute exercise on Brain-Derived Neurotropic Factor (BDNF) and cognitive performance. The FASEB Journal, 28 (1), 694.

Chang, Y. K., Alderman, B. L., Chu, C. K. et al. (2017). Acute exercise has a general facilitative effect on cognitive function: A combined ERP temporal dynamics and BDNF study. Physiology, 54 (2), 289-300.

Chang, Y. K., Chu, C. H., Wang, C. C. et al. (2015). Dose-response relation between exercise duration and cognition. Medicine \& Science in Sports \& Exercise, 47 (1), 159-165.

Crous-Bou, M., Gascon, M., Gispert, J. D. et al. (2020). Impact of urban environmental exposures on cognitive performance and brain structure of healthy individuals at risk for Alzheimer's dementia. Environment International, 138, 105546.

Drollette, E. S., Scudder, M. R., Raine, L. B. et al. (2014). Where to put your best foot forward: Psychophysiological responses to walking in natural and urban environments. Journal of Environmental Psychology, 45, 22-29.

Gidlow, C. J., Jones, M. V., Hurst, G. et al. (2015). Where to put your best foot forward: Psycho-physiological responses to walking in natural and urban environments. Journal of Environmental Psychology, 45, 22-29.

Goekint, M., Heyman, E., Roelands, B. et al. (2008). No influence of noradrenaline manipulation on acute exercise-induced increase of brain-derived neurotrophic factor. Medicine \& Science in Sports \& Exercise, 40 (11), 1990-1996.

Hillman, C. H. (2014). Acute exercise facilitates brain function and cognition in children who need it most: An ERP study of individual differences in inhibitory control capacity. Developmental Cognitive Neuroscience, 7, 53-64.

Hillman, C. H., Kamijo, K., Pontifex, M. B. (2012). The relation of ERP indices of exercise to brain health and cognition. In Functional Neuroimaging in Exercise and Sport Sciences (pp. 419-446). Springer, New York, NY.

Hillman, C. H., Snook, E. M., Jerome, G. J. (2003). Acute cardiovascular exercise and executive control function. International Journal of Psychophysiology, 48 (3), 307-314.

Ohly, H., White, M. P., Wheeler, B. W. et al. (2016). Attention Restoration Theory: A systematic review of the attention restoration potential of exposure to natural environments. Journal of Toxicology and Environmental Health, Part B, 19 (7), 305-343. 
Skirtingose aplinkose atlikto vienkartinio aerobinio krūvio poveikis vyrų kognityvinèms funkcijoms

Mozolic, J. L., Hayaska, S., Laurienti, P. J. (2010). A cognitive training intervention increases resting cerebral blood flow in healthy older adults. Frontiers in Human Neuroscience, 4, 16.

Reitan, R., Wolfson, D. (2013). The halstead-reitan neuropsychological test battery for adults: Theoretical, methodological, and validational bases. Comprehensive Handbook of Psychological Assessment: 1. Intellectual and Neuropsychological Assessment.

Secher, N. H., Seifert, T., Van Lieshout, J. J. (2008). Cerebral blood flow and metabolism during exercise: implications for fatigue. Journal of Applied Physiology, 104 (1), 306-314.

Shin, W. S., Shin, C. S., Yeoun, P. S., Kim, J. J. (2011). The influence of interaction with forest on cognitive function. Scandinavian Journal of Forest Research, 26 (6), 595-598

Skurvydas, A. (2016). Sporto mokslo naujovès žmoniu fizinès ir socialinés gerovès srityje: baltojji knyga. Kaunas: Lietuvos sporto universitetas.

Stroop, J. R. (1935). Studies of interference in serial verbal reactions. Journal of Experimental Psychology. General, 18, 643-662.

Tanaka, H., Monahan, K. D., Seals, D. R. (2001). Age-predicted maximal heart rate revisited. Journal of the American College of Cardiology, 37 (1), 153-156.

Wang, C. C., Alderman, B., Wu, C. H. et al. (2019). Effects of acute aerobic and resistance exercise on cognitive function and salivary cortisol responses. Journal of Sport and Exercise Psychology, 41 (2), 73-81.

Weinstein, A. M., Voss, M. W., Prakash, R. S. et al. (2011). The association between aerobic fitness and executive function is mediated by prefrontal cortex volume. Brain, Behavior, and Immunity, 26 (5), 811-819.

Zijlema, W. L., Triguero-Mas, M., Smith, G. et al. (2017). The relationship between natural outdoor environments and cognitive functioning and its mediators. Environmental Research, 155, 268-275.

\title{
EFFECT OF ACUTE AEROBIC EXERCISE IN DIFFERENT ENVIRONMENTS ON MEN'S COGNITIVE FUNCTION
}

\author{
Gerda Gudliauskaitė ${ }^{1}$, Ligita Šiline $\dot{e}^{1,2}$ \\ Kaunas University of Applied Sciences ${ }^{1}$ \\ Lithuanian Sports University ${ }^{2}$
}

\begin{abstract}
Background. Scientists find more and more connections between cognitive functions and physical activity, but most studies investigating the effects of acute aerobic exercise on cognitive functions are performed under laboratory conditions, so there is not enough information about the effect of acute aerobic exercises performed in different environments on cognitive functions.

Aim. The goal was to determine the effect of acute aerobic exercises performed in different environments on men's cognitive functions.

Methods. The study included 10 physically active healthy men, $23.2 \pm 2.2$ years of age. A 20-minute acute aerobic exercise was applied in a forest, a city and an indoor environment. Cognitive functions were assessed in each environment before and after exercise by "Stroop" and "Trail Making" tests.
\end{abstract}


Results. Mental flexibility $(\mathrm{p}<0.05 ; \mathrm{p}=0.01)$ significantly improved in the forest environment compared to the urban environment. It was also observed that attention $(\mathrm{p}<0.05 ; \mathrm{p}=0.01)$, reaction speed $(\mathrm{p}<0.05 ; \mathrm{p}=0.02)$ and mental flexibility $(p<0.05 ; p=0.01)$ significantly improved in the forest environment compared to the indoor environment.

Conclusions. Acute aerobic exercise performed in a quiet forest, city and indoor environments significantly improved cognitive functions. It was also observed that mental flexibility significantly improved in the forest environment, compared to the urban or indoor environment, while attention and reaction speed significantly improved in the forest environment, compared to the indoor environment.

Keywords: acute aerobic exercise, men, cognitive functions, environment.

Gautas 20200911

Priimtas 20200924 